\title{
Monetary Policy and Long Run Economic Growth in Nigeria: An Application of the Vector Error Correction Mechanism
}

\author{
Vincent Iorja Gisaor \\ Department of Economics, Federal University Wukari, Nigeria \\ gisaorvincent@gmail.com
}

\begin{abstract}
The inability of most developing economies to use monetary policy to engender real economic growth in their countries prompted the researchers to empirically assess the impact of monetary policy on economic growth in Nigeria between 1980 and 2014. The study employed an econometrics approach making use of the ADF unit root test, Johansen cointegration, Vector error correction model, Pairwise granger causality test and variance decomposition. The Vector Error Correction Mechanism result shows a positive short and long run relationship between both narrow money supply and broad money supply and economic growth in Nigeria with model strength of $75 \%$. The Pairwise granger causality test shows a bi-directional causality between broad money supply and economic growth in Nigeria and was statistically significant at $5 \%$ level of confidence. Recommendations were for the government to use her contractionary monetary efforts and implement relevant policies to curtail the inverse effect of the persistent variation in the value of exchange rate, price level and interest rate in Nigeria and adequate regulation of the quantity of money in circulation to avoid hyperinflation and other unpredictable monetary volatilities.
\end{abstract}

Keywords: Monetary Policy, Economic Growth, VECM, Nigeria

\section{How to Cite:}

Gisaor, V. I., (2021). Monetary Policy and Long Run Economic Growth in Nigeria: An Application of the Vector Error Correction Mechanism. International Journal of Finance Research. 2(2). 71-83. DOI. https://doi.org/10.47747/ijfr.v2i2.319

\section{Introduction}

It is not quite easy to define monetary policy due to differences in the level of financial development of most economies. Monetary policy may be explained as an amalgam of measures designed to regulate the value, supply and cost of money in an economy to stimulate productive economic activity in the country (Jhingan, 2006). The general objective is to ensure price stability, maintenance of external balance, reduction of unemployment, growth in output, and sustainable growth and development (Folawewo and Osunbi, 2006).

These are long run economic growth measures that are necessary for the attainment on internal and external balance for an economy. Persistent price and exchange rate volatility undermine the ability of policy makers to achieve other laudable macroeconomic objectives which makes it

Published by:

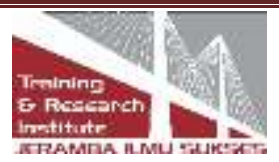


difficult for monetary authorities to achieve the role of money as a store of value, and thus discourage investment and growth. This long run inverse relationship between inflation and unemployment is popular in economic literature called the Philips curve (Jhingan, 2006).

However, the achievement of price stability will create a high degree of confidence among investors and the increasing desire on investors the government ability to manage and control her economy effectively. The transmission mechanism of monetary policy is less effective in an unstable and crisis ridden financial economy thereby making it difficult for the achievement and maintenance of strong macroeconomic fundamentals. The growth rate of Gross Domestic Product (GDP) in Nigeria for the past three decade has been poor.

This could be as a result of the failure of monetary policy in maintaining price stability in Nigeria when compared with other developing countries. GDP growth in Nigeria was significantly higher in the year 2000 than it was 35 years before. GDP recorded a negative growth rate in 1984 and 1995 (Ajisafe and Folorunso, 2002). This according to Anyanwu (1993) was inadequate to maintain a population growth rate of $2.8 \%$. In 1991, a negative GDP growth of $-0.8 \%$ was witnessed. However, the growth rate has been relatively higher since 2001 to 2015 when due to economic recession; it became completely negative between late 2015 and late 2017. The growth rate since 2001 can be said to be relatively poor when compared to other developing countries in Africa like Ghana, Cote d'Ivoire, South Africa, and Egypt (Baghebo and Ebibai, 2014).

A survey of empirical papers shows that several works such as Ajisafe and Folorunso (2002) and Folawewo and Osunbi (2006) shows that research effort have been concentrated on the impact of monetary policy on economic growth in Nigeria, but the result has been inconsistent and sometimes controversial with both positive and negative impact of monetary policy on GDP witnessed. But since monetary policy shocks are of great magnitude and concern, this has created avenue for further studies to contribute to current knowledge for updated policy making. This paper seek to improve on previous studies by employing the Vector Error Correction Model (VECM) to measure both the real and nominal effects of monetary policy on economic growth in Nigeria within the time frame of 1980 to 2014.

Monetary policy is concerned with discretionary control of money supply by the monetary authorities in order to achieve stated economic goals (Abata, Kehinde and Bolanrinwa, 2012). Governments try to control the money supply because most governments and policy makers believe that its rate of growth has an effect on the rate of inflation. Hence monetary policy comprises those government actions designed to influence the behaviour of the monetary sector. Monetary policy is a deliberate use of monetary instruments at the disposal of the monetary authorities in order to achieve a desirable economic growth (Miller, 2000). Broadly speaking, the key macroeconomic objectives of the monetary policy is to maximize the level of income, providing economic growth and development, raise the level of employment, improve balance of payments and ensure equitable distribution of economic resources (Miller, 2000). There are also a number of secondary objectives which are held to lead to maximization of income over the short and long run. While there are variations between the objectives of different national and international entities, most of them follow the ones outlined below: 
Economic Growth and Development: It is the desire of every economy to attain some considerable level of economic growth and development. These concepts are sometimes used interchangeably as if they mean the same thing. However, economic growth according to Todaro (2000) refers to an increase in a country's national output of goods and services or increase in the volume of output of goods and services within a specific period. According to Schumpeter as cited by Jhingan (2006), economic growth is a gradual and steady change in the long run which comes about by gradual increase in the rate of savings and population, while economic development is seen as a discontinuous and spontaneous change in the stationary state which forever alters and displaces the equilibrium state previously existing. Thus, while economic growth is the increase in the total output of an economy over a certain period of time, economic development means growth plus change.

Price Stability: It is also the desire of every economy to achieve price stability. Fluctuations in the level of prices render an economy unpredictable to operators. However, debate on the concept of price stability has attracted the attention of several scholars and authors. Some of the scholars see inflation as a monetary phenomenon while others see it as both monetary and nonmonetary phenomenon. Thus the debate has continued unabated with no universal consensus about the concept. Friedman as cited by Jhingan (2006) says "inflation is always and everywhere a monetary phenomenon and can be produced only by a mere rapid increase in the quantity of money than output". His view was supported by that of Hamilton (2001) when he described inflation as an economic situation when increase in money supply alone is faster than the new production of goods and services in the same economy. However, some economists disagreed with money supply alone as the cause of inflation. Hicks (1970) for example pointed out that our present troubles are not of monetary character". Melberg (1992) supported the position of Hicks when he defined inflation "as a general and persistent increase in the prices of goods and services in an economy without a corresponding increase in good supply". Most economist therefore defined inflation in terms of continued rise in prices caused by varying factors not necessarily money supply.

Full Employment: The International Labour Organization (ILO) as cited by the CBN defined unemployment as the proportion of the labour force which was available for work but did not work for at least one hour in the week preceding the survey period (CBN, 2007). The National Bureau of Statistics (NBS) as cited by the CBN defined unemployment as the proportion of the labour force that is available for work but did not work for at least 39 hours in the week preceding the survey period (CBN, 2007). The two definitions above have been seriously criticized for structural deformity. Not everyone who is available for work but did not work is unemployed. This led to the definition given by Miller (2000) when he defined unemployment as adults who are able, qualified and willing to work but have no job. The definition of Miller provides a better treatment of the subject matter of unemployment. For one to be unemployed, he/she must be able not disable, he must be trained with the skill to do the work in question and most importantly, be willing to do the work at the going wage rate in the labour market.

Balance of Payments Equilibrium: Balance of payments refers to the statistical relationship between a country's export and import in a given period of time usually one year. It refers to equilibrium in the balance of payments without the use of artificial constraints. That is, exports 
roughly equal to imports over the long run. The key factors affecting balance of payments in most countries is the volume of production and exchange rate (Miller, 2000). In Nigeria, foreign exchange rate is the rate at which the naira is exchanged with other major currencies of the world like US Dollar and Pound Sterling.

Income Redistribution: This involves the use of credit policies to influence and regulate the economy. It implies that when income distribution in the economy is skewed in favour of the rich, government reduces it by imposing some monetary restrictions. This in turn reduces aggregate private spending which is dependent upon government expenditure. On the other hand, government issues out incentives and the use of open market operations to boost the purchasing power of the people or business companies (Miller, 2000).

\section{Literature Review}

Two fundamental propositions about the effect of the quantity of money on the economy predate the emergence of monetary economics as a recognized discipline of study. The first is that increases in the quantity of money that is not associated with the corresponding increase in real output will eventually lead to inflation, and the second is that a shortage of money can depress the volume of economic activity. A considerable literature has emerged, attempting to give credence or discordance to these propositions, using parsimoniously restricted multivariate time series models as Sims and Zha (2005) discussed. Friedman and Schwartz (1963) inspired the campaign in their seminal work as they documented the strong time series correlation of monetary aggregates with both output and prices. They explained that these correlations did not primarily represent passive responses of monetary aggregates to development in the private sector, but instead mainly the effects on monetary policy shifts on the private sector (Nagel and Parker, 2003). From their argument, it follows that innovation in monetary policy variables have the potential for stimulating the economy when it is sluggish or cooling it down when it overheats.

The literature had identified several factors that determine the capacity of central banks to use monetary policy innovations to achieve counter cyclical objectives in the economy. One of such factors is the credibility of monetary policy. In this regard, credibility refers to the level of commitment of the central bank to following a set down monetary policy rule rather than following a discretionary approach. This is important because economic agents make their decisions based on the expected course of monetary policy as well as the current policy. Also, policy transparency which deals with the extent of policy disclosure and the timing of central bank communication according to Geraats (2005) are key success factors in evaluating the effectiveness on monetary policies.

However, Leeper (1996) and Bernanke and Mihov (1998) prefer to make the case for the choice of the monetary instrument used for intervention as the major determinant of the degree of impact. They both submit that the traditional approach of using changes in the money stock to stimulate or depress economic activity is inferior to the use of interest rate. This is because the growth rate on monetary aggregates depends on the variety of non-policy influences. Starr (2005) in the spirit of the new Keynesianism, focused mainly on the sticky and flexible nature of prices. No matter the opinion that different authors may hold about the major determinants of the 
effectiveness of monetary policy, it is certain that the effectiveness of monetary policy shocks, is a function of a compound set of variables.

In the developed economies such as the United States of America (USA) and in some core European countries, there is substantial evidence of the effectiveness of monetary policy innovations on real economic parameters (Mishkin, 2002). However, for developing economies like Nigeria, the evidence is weak. For instance, Balogun (2007) used simultaneous equation models to test the hypothesis of monetary policy ineffectiveness in Nigeria and find that, rather than promote growth; erstwhile domestic monetary policy was the source of stagnation and persistent inflation. The idiosyncratic evidence inconsistent with theoretical expectations returned from different investigations in different countries is what economists usually refer to as "puzzles".

The three most common puzzles identified in the literature are: the liquidity puzzle, the price puzzle and the exchange rate puzzle. The liquidity puzzle is a finding that an increase in monetary aggregates is accompanied by an increase in interest rate. The price puzzle is the finding that contractionary monetary policy through positive innovations in the interest rate seems to lead to an increase in prices. And yet, the common in open economies is the exchange rate puzzle, which is a finding that an increase in interest rate is associated with depreciation of the local currency.

In contemporary studies, researchers have decided to use a convenient way of eradicating these puzzles. Most of them now follow the framework set by Lucas (1972) who recommended for the incorporation of rational expectations in the studies of the effects of monetary policy. Some recent papers that follow this approach are: Brument and Dincer (2008) and Zhang (2009). In our present study, all the monetary aggregates that constitute the three puzzles, money supply, interest rate, inflation rate and exchange rate are both incorporated into a dynamic VECM to examine in totality, the real effects of monetary policy on economic growth in Nigeria.

Folawewo and Osinubi (2006) investigated how monetary policy objectives of controlling inflation rate and intervention in financing of fiscal deficits affect the variability of inflation and exchange rate in Nigeria. Rational expectation that incorporates fiscal role of exchange rate was the basis of analysis. The result shows that inflation affects volatility of its own rate as well as the rate of real exchange. The study recommended for a clear and well articulated monetary policy devoid of ambiguity for easy implementation.

Chuku (2009) investigated the effects of monetary policy innovations in Nigeria using structural vector auto-regression model. He found evidence that monetary policy innovation in Nigeria positively affected the growth of output. He further concluded that the manipulation of the quantity of money supply in Nigeria is the most important and useful monetary instrument. The recommendation made was for the central bank to place more emphasis on the use of quantitybased nominal anchor rather than price-based nominal anchors.

Abata, Kehinde and Bolarinwa (2012) assess how fiscal and monetary policies influence economic growth and development in Nigeria using multiple regression equation and time series data from 1986 to 2000. The research reveals that there exist a mild long run equilibrium 
relationship between economic growth and fiscal policy variables in Nigeria. The paper suggested for any meaningful progress towards fiscal prudence on the part of government to help reduce the current fiscal rascality. Again, this paper has a different focus with the present research.

The work of Baghebo and Ebibai (2014) examined the impact of monetary policy on economic growth in Nigeria using time series data from 1980 to 2011 using OLS regression analysis. The result shows a positive influence of monetary policy variables on economic growth during the period of analysis. The authors suggested for the promotion of a most friendly investment environment in Nigeria to sustain increased in GDP growth rate. This work is quite good and current but can still be criticized for using an OLS for such volatile and dynamic variables like money supply and exchange rate.

\section{Research Method}

The study used only secondary data generated from 2014 CBN bulletin. The primary model showing the technical relationship between monetary policy proxied by narrow money supply (M1) and broad money supply (M2) and real gross domestic product (RGDP) as a proxy for economic growth in Nigeria was specified thus:

$\mathrm{RGDP}=\mathrm{F}(\mathrm{NMS}+\mathrm{BMS})$

Equation (3.1) was easily expanded to cover other monetary related variables affecting economic growth in Nigeria as follows:

$\mathrm{RGDP}=\mathrm{F}(\mathrm{NMS}+\mathrm{BMS}+\mathrm{EXR}+\mathrm{CPI}+\mathrm{INTR}$

The non stochastic implicit model is therefore explicitly specified to cover the stochastic random element as follows:

$\mathrm{RGDP}=\mathrm{b}_{0}+\mathrm{b}_{1} \mathrm{NMS}+\mathrm{b}_{2} \mathrm{BMS}+\mathrm{b}_{3}+\mathrm{EXR} \mathrm{b}_{4} \mathrm{CPI}+\mathrm{b}_{5} \mathrm{INTR}+\mathrm{U}$

Where; $b_{0}=$ Intercept or gradient; $b_{1}-b_{5}=$ Parameter coefficients to be estimated; RGDP $=$ Real Gross Domestic Product; NMS=Narrow Money Supply; BMS=Broad Money Supply; EXR = Exchange Rate; $\mathrm{CPI}=$ Consumer Price Index as a proxy for inflation rate; INTR = Interest Rate. On a priori theoretical expectation, it was expected that all the independent variables except EXR and INTR would positively related the dependent variable in the model (RGDP). 


\subsection{ADF Unit Root Test}

\section{Table1 ADF Unit Root Test at Levels}

\begin{tabular}{|l|l|l|l|}
\hline Variables & ADF values at levels & Mackinon values 5\% & Order of integration \\
\hline RGDP & 3.24958 & -2.971853 & $1(0)$ \\
\hline NMS & 6.135051 & -2.963972 & $1(0)$ \\
\hline BMS & 1.410334 & -2.960411 & Not stationary \\
\hline EXR & -0.058181 & -2.951125 & Not stationary \\
\hline CPI & -3.922500 & -2.954021 & $1(0)$ \\
\hline INTR & -4.134094 & -2.951125 & $1(0)$ \\
\hline
\end{tabular}

Source: Eviews 8.0 Output, 2021

The Mackinnon values give the critical values for the determination of stationarity and order of integration as well. The absolute value of the Mackinnon and the ADF test statistics are compared and decisions to accept or reject the in-built hypothesis in the ADF are taken. The result of Table 1 above shows four of the variables - RGDP, NMS, CPI and INTR to be stationary at levels. BMS and EXR were not stationary at levels. This means that the two variables have violated the stochastic assumptions of the OLS.

\section{Table 2 ADF Unit Root Test at First Difference}

\begin{tabular}{|l|l|l|l|}
\hline Variables & ADF values at levels & Mackinon values 5\% & Order of integration \\
\hline RGDP & 6.538205 & -2.971853 & $1(1)$ \\
\hline NMS & 7.062699 & -2.986225 & $1(1)$ \\
\hline BMS & -6.449779 & -2.957110 & $1(1)$ \\
\hline EXR & -6.716486 & -2.954021 & $1(1)$ \\
\hline CPI & -5.661661 & -2.960411 & $1(1)$ \\
\hline INTR & -7.610889 & -2.957110 & $1(1)$ \\
\hline
\end{tabular}

Source: Eviews 8.0 Output, 2021

The ADF test at first difference is presented in Table 2 above. The results show all the variables - RGDP, NMS, BMS, CPI, EXR and INTR to be stationary at first difference. No variable has violated the stochastic assumptions of the OLS at this level. Thus, we employ the Johansen cointegration to investigate for both the short and long run cointegration of the series.

The Johasen cointegration test displayed in Table 3 below shows that, both the trace test the maximum eigenvalues both have unanimously agreed to produce two conitegrating equations at $5 \%$ confidence level. In this event of no disagreement between trace and maximum eigenvalue, we reject the null hypothesis and accept the alternative hypothesis of many conitegrating equations.

Johasen Cointegration Test

Published by: 
Table 3 Johasen Cointegration Result

Series: RGDP NMS BMS EXR CPI INTR

\begin{tabular}{ccccc}
\hline \hline $\begin{array}{c}\text { Hypothesized } \\
\text { No. of CE(s) }\end{array}$ & Eigenvalue & $\begin{array}{c}\text { Trace } \\
\text { Statistic }\end{array}$ & $\begin{array}{c}0.05 \\
\text { Critical Value }\end{array}$ & Prob. * $^{*}$ \\
\hline \hline None * & 0.788469 & 131.5282 & 95.75366 & 0.0000 \\
At most 1 * & 0.717011 & 80.26652 & 69.81889 & 0.0058 \\
At most 2 & 0.474128 & 38.60900 & 47.85613 & 0.2761 \\
At most 3 & 0.302502 & 17.40000 & 29.79707 & 0.6104 \\
At most 4 & 0.143273 & 5.511544 & 15.49471 & 0.7523 \\
At most 5 & 0.012304 & 0.408562 & 3.841466 & 0.5227 \\
\hline \hline
\end{tabular}

Trace test indicates 2 cointegrating eqn(s) at the 0.05 level

* denotes rejection of the hypothesis at the 0.05 level

* * MacKinnon-Haug-Michelis (1999) p-values

Unrestricted Cointegration Rank Test (Maximum Eigenvalue)

\begin{tabular}{ccccc}
\hline \hline $\begin{array}{c}\text { Hypothesized } \\
\text { No. of CE(s) }\end{array}$ & Eigenvalue & $\begin{array}{c}\text { Max-Eigen } \\
\text { Statistic }\end{array}$ & $\begin{array}{c}0.05 \\
\text { Critical Value }\end{array}$ & Prob. * $^{*}$ \\
\hline \hline None * & 0.788469 & 51.26164 & 40.07757 & 0.0019 \\
At most $1{ }^{*}$ & 0.717011 & 41.65751 & 33.87687 & 0.0048 \\
At most 2 & 0.474128 & 21.20901 & 27.58434 & 0.2638 \\
At most 3 & 0.302502 & 11.88845 & 21.13162 & 0.5587 \\
At most 4 & 0.143273 & 5.102982 & 14.26460 & 0.7288 \\
At most 5 & 0.012304 & 0.408562 & 3.841466 & 0.5227 \\
\hline \hline
\end{tabular}

Max-eigenvalue test indicates 2 cointegrating eqn(s) at the 0.05 level

* denotes rejection of the hypothesis at the 0.05 level

${ }^{*}$ * MacKinnon-Haug-Michelis (1999) p-values

Source: Eviews 8.0 Output, 2021

\section{Vector Error Correction}

The VECM long run effect shows a long run positive relationship between NMS and BMS and RGDP in Nigeria. There is however, a negative relationship between EXR, CPI and INTR and GDP in Nigeria in the long run. The implication is simple; the current rate of exchange, price level and the cost of borrowing are too high for a comfortable growth of the Nigerian economy

Table 4 VECM Long Run Effects

Published by: 
Vector Error Correction Estimates Standard errors in ( ) \& t-statistics in [ ]

\begin{tabular}{cc}
\hline \hline Cointegrating Eq: & CointEq1 \\
\hline \hline RGDP(-1) & 1.000000 \\
& 49926.70 \\
NMS(-1) & {$[66029.2)$} \\
& 4282.507 \\
& $(378.838)$ \\
BMS(-1) & {$[11.3043]$} \\
& -114339.7 \\
& $(28790.4)$ \\
EXR(-1) & {$[-3.97145]$} \\
& -377686.2 \\
& $(71398.1)$ \\
CPI(-1) & {$[-5.28986]$} \\
& -469.6843 \\
& $(96517.6)$ \\
INTR(-1) & {$[-0.00487]$} \\
& 19595852 \\
C &
\end{tabular}

Source: Eviews 8.0 Output, 2021

The ECM value of -0.428172 carries the correct sign and indicate a speed of adjustment to a unique equilibrium after a policy shock of $42.8 \%$. The model has a high speed of adjustment. The VECM short run effect also shows a short run positive relationship between both the NMS and BMS and GDP in Nigeria. There is again, a negative relationship between EXR, CPI and INTR and RGDP in Nigeria in the short run. The R2 and adjusted R2 are all positive with 75\% and $67 \%$ respectively. This indicates that the model has a good fit with $75 \%$ of the variations in the dependent variable explained by the explanatory variables in the model. The remaining $25 \%$ is left for the stochastic error term

\section{.Table 5 VECM Short Run Effects}

Published by: 
Vol. 2, No. 2, June 2021

Error Correction:

D(RGDP)

\begin{tabular}{|c|c|}
\hline CointEq1 & $\begin{array}{r}-0.428172 \\
(0.15350) \\
{[-2.78931]}\end{array}$ \\
\hline D(NMS(-1)) & $\begin{array}{c}71164.71 \\
(63259.3) \\
{[1.12497]}\end{array}$ \\
\hline $\mathrm{D}(\mathrm{BMS}(-1))$ & $\begin{array}{c}2547.158 \\
(2866.94) \\
{[0.88846]}\end{array}$ \\
\hline $\mathrm{D}(\operatorname{EXR}(-1))$ & $\begin{array}{r}-92723.18 \\
(90097.8) \\
{[-1.02914]}\end{array}$ \\
\hline $\mathrm{D}(\mathrm{CPI}(-1))$ & $\begin{array}{r}-53747.48 \\
(65384.7) \\
{[-0.82202]}\end{array}$ \\
\hline $\mathrm{D}(\operatorname{INTR}(-1))$ & $\begin{array}{r}-12837.19 \\
(69099.3) \\
{[-0.18578]}\end{array}$ \\
\hline $\mathrm{C}$ & $\begin{array}{c}4025455 . \\
(1875641) \\
{[2.14618]}\end{array}$ \\
\hline R-squared & 0.754085 \\
\hline Adj. R-squared & 0.673229 \\
\hline Sum sq. resids & $1.16 \mathrm{E}+15$ \\
\hline S.E. equation & 6819490. \\
\hline F-statistic & 1.957825 \\
\hline Log likelihood & -561.5088 \\
\hline Akaike AIC & 34.51568 \\
\hline Schwarz SC & 34.87847 \\
\hline Mean dependent & 2660950 . \\
\hline S.D. dependent & 7499964 . \\
\hline
\end{tabular}

Source: Eviews 8.0 Output, 2021

The Pairwise granger causality test shows a bi-directional causation running between GRE and GDP. No causation running from GCE to GDP and a uni-directional causation running from both NMS and BMS to RGDP in Nigeria. The result shows no causation between EXR, CPI and INTR to economic growth in Nigeria. 


\section{Pairwise Granger Causality Tests}

\section{Table 4.6 Pairwise Granger Causality Test}

Pairwise Granger Causality Tests

Date: 06/28/16 Time: 11:41

Sample: 19802014

Lags: 2

\begin{tabular}{|c|c|c|c|}
\hline Null Hypothesis: & Obs & F-Statistic & Prob. \\
\hline NMS does not Granger Cause RGDP & \multirow[t]{2}{*}{33} & 0.55509 & 0.0502 \\
\hline RGDP does not Granger Cause NMS & & 1.28283 & 0.0230 \\
\hline BMS does not Granger Cause RGDP & \multirow[t]{2}{*}{33} & 2.26997 & 0.0220 \\
\hline RGDP does not Granger Cause BMS & & 8.47171 & 0.0013 \\
\hline EXR does not Granger Cause RGDP & \multirow[t]{2}{*}{33} & 1.04746 & 0.3642 \\
\hline RGDP does not Granger Cause EXR & & 0.33914 & 0.7153 \\
\hline CPI does not Granger Cause RGDP & \multirow[t]{2}{*}{33} & 0.09839 & 0.9066 \\
\hline RGDP does not Granger Cause CPI & & 0.85977 & 0.4341 \\
\hline INTR does not Granger Cause RGDP & \multirow[t]{2}{*}{33} & 0.38505 & 0.6840 \\
\hline RGDP does not Granger Cause INTR & & 2.39746 & 0.1094 \\
\hline
\end{tabular}

Source: Eviews 8.0 Output, 2021

\section{Conclusion}

There is a persistent variation in the value of exchange rate, price level and interest rate in Nigeria lately, monetary efforts in terms of policy by the authority should be put in place to curtail the inverse effect of the growth in these monetary variables in the country.

Money is like a fluid lubricating the smooth operation of an economy. However, the quantity in circulation should be regulated to avoid hyperinflation and other unpredictable monetary consequences.

Monetary policy operations in the country should be operated with great transparency and accountability considering that, they have a direct link to economic growth and development of Nigeria.

Economic growth and development is not only a function of monetary policy but also fiscal policy as well. There is therefore need for appropriate monetary and fiscal policy mix for a more stabilized macroeconomic atmosphere in Nigeria. 


\section{References}

Abata, M. A., Kehinde, J. S. and Bolarinwa, S. A. (2012) Fiscal/Monetary Policy and Economic Growth in Nigeria: A Theoretical Approach. International Journal of Academic Research in Economics and Management Sciences. Vol. 1, No. 2 pp 75-88

Ajisafe, R. A. and Folorunso, B. A. (2002) The Relative Effectiveness of Monetary and Fiscal Policy in Macroeconomic Management in Nigeria. African Economic and Business Review vol.3 no.1. Spring

Anyanwu, J. C. (1993) Monetary Economics Theory, Policy and Institutions. Hybrid Publishers

Baghebo, M and Ebibai, T. S. (2014) Monetary Policy and Economic Growth in Nigeria. Asian Economic and Financial Review. 4 (1) 20-32

Balogun, E. (2007) Monetary Policy and Economic Performance in West African Monetary Zone. MPRA Paper No. 3408

Bernanke, B. and Mihov, I. (1998) Measuring Monetary Policy. The Quarterly Journal of Economics. 3. Pp 870-902

Berumen, H and Dincer, N. (2008) Measuring Monetary Policy for Turkey. Journal of Economics Cooperation 29 (1) pp 83-110

Central Bank of Nigeria (2007) Statistical Bulletin, 2007.

Chuku, A. C. (2009) Measuring the Effect of Monetary Policy Innovation in Nigeria. A Structural Vector Autoregressive Approach. African Journal of Accounting, Economics, Finance and Banking Research. Vol. 5 No 5 pp112-129

Folawewo, A. O. and Osinubi, T. S. (2006) Monetary Policy and macroeconomic Instability in Nigeria. A Rational Expectation Approach. Journal of Social Science. 12 (2) 93-100

Friedman M. and Schwartz, A (1963) A Monetary History of USA. Princeton University Press.

Geraats, P. (2005) Transparency of Monetary Policy; Theory and Practice. Research Paper, Center for Economic Studies Munich.

Hamilton, E. J. (2001) American treasure and the price revolution in Spain: Harvard Economic Studies; Cambridge- Massachusetts; Harvard University Press.

Jhigan, M. L. (2006) Advanced Economic Theory. Vrinda Publications Delhi, India.

Leeper, E. Christopher, S. and Zha, T. (1996) What does monetary policy do? Brookings paper on Economic Activity (92) pp 1-63

Lucas, R, J. (1972) Expectations and the Neutrality of Money. Journal of Economic Theory 4 (2) PP 103-144

Melberg, H. O. (1992) Inflation: An Overview of Theories and Solution, www.geocites.com/hmelberg/papers/921201.htm

Miller, R. L. (2000) Economics Today. Addison Wesley Longman Inc, 1999-2000 Edition. 
Mishkin, F. (2002) The Role of Output Stabilization in the Conduct of Monetary Policy. IMF Working paper No 9291 NBER

Nagel A. Parker, J (2009) Empirical Macroeconomics. The Effects of Monetary Policy. Paper presented at the Gold-Hammer Collaborative Research at Reed College

Rafiq, M. S. and Mallick, S. K. (2008) The Effect of Monetary Policy on Output in EMU: A Sign Restriction Approach. Journal of Macroeconomics. (30) pp 1756- 1791

Sims, C and Zha, T. (2005) Does Monetary Policy Generate Recessions. Research Paper. Federal Reserve Bank of Atlanta.

Starr, M (2005) Does Money matter in the CIS? Effects of Monetary on output and prices. Journal of Comparative Economics (33) 441-461

Todaro, M. P. (2000) Economics of Development. New York University and the Population Council, 12th Edition.

Zhang, W. (2009) China's Monetary Policy. Quantity Versus price Rules. Journal of Macroeconomics. (31) 473-484

Copyrights

Copyright for this article is retained by the author(s), with first publication rights granted to the journal.

This is an open-access article distributed under the terms and conditions of the Creative Commons Attribution license (http://creativecommons.org/licenses/by/4.0/) 